\title{
PENERAPAN MODEL PEMBELAJARAN KOOPERATIF TIPE OPEN-ENDED UNTUK MENINGKATKAN KEMAMPUAN BERPIKIR KREATIF MATEMATIS SISWA KELAS IV SDN 101/X LAMBUR I
}

\author{
Yuli Amaliyah $^{1}$, Mardiana ${ }^{2}$, Panut Setiono ${ }^{3}$ \\ STAI Ahsanta Jambi ${ }^{1,2}$ \\ Universitas Bengkulu ${ }^{3}$ \\ e-mail: yuliamaliyah405@gmail.com
}

\begin{abstract}
ABSTRAK
Penelitian ini bertujuan untuk bertujuan untuk meningkatkan kemampuan berpikir kreatif matematis siswa kelas IV SDN 101/X Lambur I dengan penerapan model pembelajaran kooperatif tipe Open-Ended. Penelitian ini merupakan penelitian tindakan kelas yang dilaksanakan di SDN 101/X Lambur I. Subjek penelitian ini adalah siswa kelas V SDN 101/X Lambur I dengan jumlah 24 orang siswa. Hasil penelitian memperlihatkan pembelajaran kooperatif tipe Open-Ended dapat meningkatkan keterampilan berpikir kreatif matematis siswa. Keterampilan berpikir kreatif matematis siswa setelah penerapan model pembelajaran Kooperatif Open-Ended dari siklus I ke siklus II meningkat Sebesar $16,7 \%$ atau terdapat penambahan sebanyak 4 orang anak yang memiliki kemampuan berpikir kreatif matematis dengan kategori 'Sangat Baik' dari sebelumnya. Selain itu terdapat kenaikan Sebesar 25\% atau terdapat penambahan 6 orang anak yang memiliki kemampuan berpikir kreatif matimatis dengan kategori 'Baik'.
\end{abstract}

\section{Kata kunci :}

Pembelajaran Kooperatif Tipe Open-Ended; Kemampuan Berpikir Kreatif Matematis.

\begin{abstract}
This study aims to improve the mathematical creative thinking skills of fourth grade students of SDN 101 / X Lambur I by applying the Open-Ended type of cooperative learning model. This research is a classroom action research conducted at SDN 101 / X Lambur I. The subjects of this study were 24 students of class V SDN 101/X Lambur I. The results showed that the Open-Ended type of cooperative learning can improve students' mathematical creative thinking skills. Students' mathematical creative thinking skills after the application of the Open-Ended Cooperative learning model from cycle I to cycle II increased by $16.7 \%$ or there was an addition of 4 children who had the ability to think mathematically creatively with the 'Very Good' category from before. In addition, there is an increase of $25 \%$ or there is an addition of 6 children who have deadly creative thinking skills in the 'Good' category.
\end{abstract}

Keywords :

Open-Ended Cooperative Learning Type; Mathematical Creative Thinking Ability.

\section{PENDAHULUAN}

Pendidikan adalah usaha sadar dan terencana untuk mewujudkan suasana belajar dan proses pembelajaran agar peserta didik secara aktif mengembangkan potensi dirinya untuk memiliki kekuatan spiritual keagamaan, pengendalian diri, kepribadian, kecerdasan, akhlak mulia, serta keterampilan yang diperlukan dirinya, masyarakat, bangsa, dan negara (UU No. 20 Tahun
2003). Pendidikan memiliki kekuatan (pengaruh) yang dinamis dalam kehidupan manusia di masa depan. Pendidikan dapat mengembangkan berbagai potensi yang dimiliki oleh peserta didik secara optimal, yaitu pengembangan potensi individu yang setinggi-tingginya dalam aspek fisik, intelektual, emosional, social dan spiritual, sesuai dengan tahap perkembangan serta karakteristik lingkungan fisik dan 
lingkungan social budaya dimana dia hidup. Pendidikan harus mampu mengembangkan diri seseorang sebagai individu yang utuh, sebagai anggota masyarakat, sebagai warga bangsa.

Permendikbud No.22 Tahun 2016 Tentang Standar Proses Pendidikan dasar dan Menengah menyatakan bahwa pembelajaran kurikulum 2013 menekankan prinsip pembelajaran yang awalnya siswa diberi tahu menuju siswa mencari tahu konsep keilmuannya sendiri. Menurut Rafianti, Yani dan Novaliyosi (2018) dalam kurikulum 2013 terdapat aspek penguatan dan pendidikan karakter (PPK) atau Creative, Critical Thingking, Communicative, Collaborative dan HOTS (Higher Order Thinking Skill). Salah satu tuntutan kurikulum 2013 adalah siswa memiliki kemampuan berpikir kreatif dimana siswa dituntut untuk menemukan konsep keilmuannya sendiri disertai kreativitasnya.

Matematika merupakan salah satu mata pelajaran menuntut siswa untuk berpikir kritis, kratif dalam memecahkan soal atau permasalahan yang berkaitan dengan kehidupan sehari-hari dan selalu berkaitan dengan kehidupan nyata dialami Peserta didik. Namun, mata pelajaran matematika sering menjadi mata pelajaran yang paling dihindari oleh peserta didik. Ini terjadi karna anggapan peserta didik terhadap mata pelajaran matematika itu sulit, menakutkan, proses pembelajarannya monoton sehingga kurangnya antusias peserta didik untuk mempelajarainya.

Berdasarkan hal tersebut, peneliti bermaksud untuk meneliti pembelajaran matematika yang dilaksanakan di SDN 101/X Lambur I. Hasil observasi yang dilakukan di kelas IV SDN 101/X Lambur I diperoleh beberapa masalah yang ditemukan dalam proses pembelajaran yaitu: (1) kemampuan siswa dalam memahami konsep dan memecahkan masalah masih rendah (2) (3) pembelajaran yang dilakukan guru masih bersifat konvensional, artinya pembelajaran hanya dilakukan dengan menjelaskan teori, pemberian contoh, dan diakhiri dengan latihan soal-soal.

Berdasarkan permasalahan yang telah diungkapkan diatas, menunjukkan bahwa diperlukan suatu perubahan cara mengajar yang dilakukan oleh guru. Perubahan dapat dilakukan dengan menerapkan model pembelajaran kooperatif dengan tipe OpenEnded.

Model pembelajarn kooperatif OpenEnded yaitu model pembelajaran yang mengutamakan proses dari hasil. Dalam pembelajaran ini siswa dihadapkan dengan masalah yang mana siswa dituntut untuk dapat mengembangkan metode atau cara yang berbeda-beda dalam upaya memperoleh jawaban yang benar (Kurnia Eka Lestari \& Mokhammad Ridwan Yudhanegara, 2017).

Model pembelajaran Open-Ended merupakan salah satu model pembelajaran matematika guna membiasakan peserta didik unruk menemukan solusi atau pemecahan dari masalah, dimana permasalahan yang disajikan memiliki pemecahan yang disajikan memiliki pemecahan berbagai cara. Belajar matematika dengan melibatkan masalah Open-Ended dapat menantang, mengakomodasi berbagai gaya belajar peserta didik. Aktivitas dan variasi alami dalam memecahkan masalah membantu peserta didik dalam mengembangkan dan mendemonstrasikan kemampuan berpikir kreatifnya secara matematis

\section{METODE PENELITIAN}

Metode penelitian ini menggunakan metode penelitian kualitatif, dengan jenis Penelitian Tindakan Kelas (PTK). Metode pengumpulan data dengan observasi. Teknik analisis data dengan menggunakan teknik analisis model Miles dan Huberman yaitu merangkum, menyajikan data dan memberikan kesimpulan. 
Penelitian tindakan kelas ini dilaksanakan di Kelas IV SDN 101/X Lambur I Penelitian ini dilaksanakan pada Semester Ganjil tahun pelajaran 2018/2019. Subjek penelitian ini peserta didik kelas IV SDN 101/X Lambur I yang berjumlah 24 orang.

\section{HASIL DAN PEMBAHASAN Deskripsi Data}

Prosedur penelitian yang dilakukan menggunakan prosedur penelitian tindakan kelas dari Kemmis dan Mc Taagart (dalam Arikunto, 2016) terdiri dari tahapan perencanaan, pelaksanaan, observasi dan refleksi yang dapat digambarkan sebagai berikut:

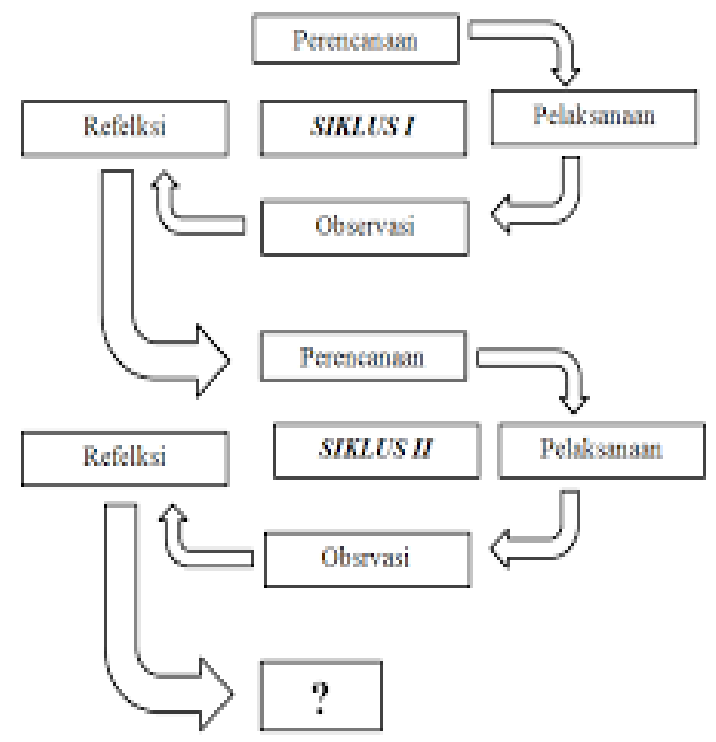

Gambar 1. Siklus PTK menurut Kemmis \& MC Taggart

Penelitian tindakan kelas yang dilakukan terdiri dari 2 siklus yang dilaksanakan mulai bulan Juli 2019 sampai dengan September 2019. Tindakan yang diberikan berupa penerapan model pembelajaran kooperatif tipe Open-Ended dalam proses pembelajaran materi perbaikan. Pembelajaran Open-Ended dilaksanakan melalui 3 fase (Lestari, K.E., \& Yudhanegara, M. R., 2015) yaitu; (1)fase open-ended problems, pada fase ini siswa dihadapkan pada masalah terbuka yang memiliki lebih dasri satu jawaban atau metode penyelesaian; (2) fase contructivism, pada fase ini siswa menemukan pola untuk mengkontruksi permasalahan sendiri; (3)fase exploration, pada fase ini siswa menyelesaikan masalah dengan banyak cara penyelesaian melalui kegiatan eksplorasi; (4) fase presentation, pada fase ini siswa menyajikan hasil temuannya.

Langkah-langkah Open-Ended dalam pembelajaran terdiri dari; 1) siswa membentuk kelompok yang terdiri dari 5 orang, 2)siswa mendapat pertanyaan open ended problem dari guru, 3)siswa melakukan diskusi dengan kelompoknya dalam memecahkan masalah Open-Ended yang diberikan guru, 4)setiap kelompok memiliki perwakilan untuk mempresentasikan hasil penyelesaianan masalah Open-Ended, 5)siswa menganalisis jawaban-jawaban beberapa teman yang mempresentasikan ke depan dan melihat mana jawaban yang benar dan lebih efektif.

\section{Siklus I}

Berdasarkan pembelajaran yang dilakukan pada siklus I siswa Kelas IV SDN 101/X Lambur I dengan penerapan model pembelajaran kooperatif tipe Open-Ended, bahwa terjadi peningkatan kemampuan berpikir kreatif matematis sesuai dengan indikator. Kategori berpikir kreatif matematis siswa diperoleh dari hasil analisis jawaban mahasiswa pada prasiklus dan siklus I serta dilihat dari kemampuan siswa dalam memenuhi aspek berpikir kreatif matematis. Dari data yang diperoleh kemampuan berpikir kreatif matematis siswa diinterprestasikan ke dalam 4 soal pada siklus I. Adapun rekapitulasi presentase kemampuan berpikir kreatif matematis pada pra siklus dan siklus I siswa kelas IV SDN 101/X Lambur I pada masing masing kategori dapat dilihat pada tabel 1 
Tabel 1. Rekapitulasi jumlah siswa tiap kategori kemampuan berpikir kreatif matematis Pra Siklus dan siklus I

\begin{tabular}{|c|c|c|c|}
\hline Ketentuan & Kategori & Jumlah Siswa Prasiklus & Jumlah Siswa Siklus I \\
\hline $90 \leq x \leq 100$ & Sangat Baik & 0 & 1 \\
\hline $80 \leq x \leq 90$ & Baik & 2 & 4 \\
\hline $70 \leq x \leq 80$ & Cukup & 4 & 6 \\
\hline $60 \leq x \leq 70$ & kurang & 15 & 12 \\
\hline$x \leq 60$ & Sangat Kurang & 3 & 1 \\
\hline & $\Sigma$ & 24 & 24 \\
\hline
\end{tabular}

Secara visual perbandingan mahasiswa yang menempati kelima kategori tersebut dapat dilihat pada gambar 2 .

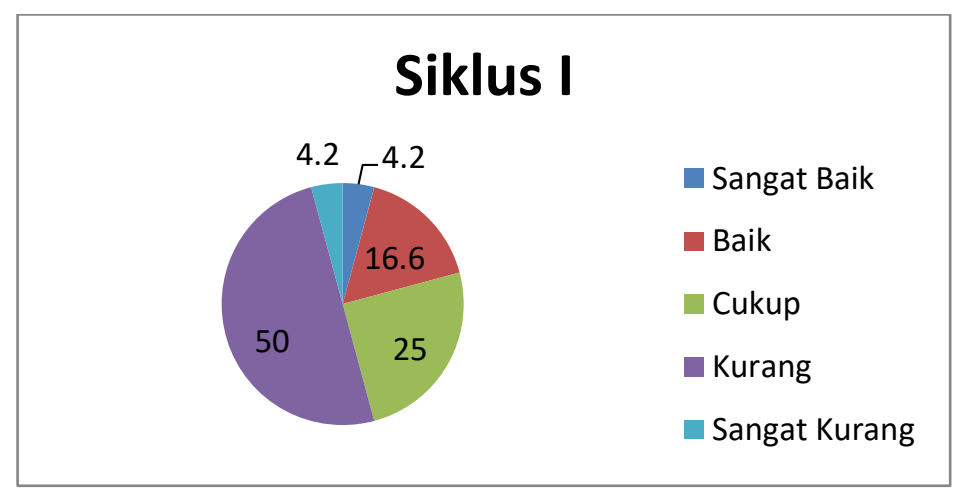

Gambar 2. Kemampuan Siswa Siklus I

Berdasarkan Tabel 1 dan gambar 1, Rata-rata nilai yang diperoleh siswa adalah sebesar 68,2 nilai maksimal yang diperoleh siswa adalah 93 dan nilai minimal yang diperoleh adalah 54. Hasil presentase dari prasiklus dan siklus I yaitu

a. Terdapat kenaikan Sebesar 4,2\% atau terdapat seorang anak yang memiliki kemampuan berpikir kreatif matematis dengan kategori 'Sangat Baik' dari sebelumnya pada prasiklus tidak ada anak yang memiliki kemampuan berpikir pada kategori ini.

b. Terdapat kenaikan Sebesar $8,3 \%$ atau terdapat penambahan 2 orang anak yang memiliki kemampuan berpikir kreatif matimatis dengan kategori 'Baik'.

c. Terdapat kenaikan Sebesar $8,3 \%$ atau terdapat penambahan 2 orang anak yang memiliki kemampuan berpikir kreatif matimatis dengan kategori 'Cukup'

d. Berkurang sebanyak 3 orang anak atau terdapat penurunan sebesar $12,5 \%$ yang memiliki kemampuan berpikir kreatif matimatis dengan kategori 'Kurang'. e. Berkurang sebanyak 2 orang anak atau sebesar 8,3\%yang memiliki kemampuan berpikir kreatif matimatis dengan kategori 'Sangat Kurang'.

\section{Siklus II}

Berdasarkan pembelajaran yang dilaksanakan pada siklus II pada siswa kelas IV SDN 101/X Lambur I dengan penerapan model pembelajaran Kooperatif tipe OpenEnded bahwa terjadi peningkatan kemampuan berpikir kreatif matematis siswa yang sesuai dengan indikator. Kategori berpikir kreatif matematis siswa siswa diperoleh dari; (1)hasil analisis jawaban siswa pada siklus I dan siklus II, dan (2)kemampuan siswa dalam memenuhi aspek berpikir kreatif matematis siswa yang diinterprestasikan ke dalam 6 soal pada siklus II. Adapun Rekapitulasi presentase kemampuan berpikir kreatif matematis siswa kelas IV SDN 101/X Lambur I dapat dilihat pada masing-masing kategori pada table di bawah 2. 
Tabel 2. Rekapitulasi jumlah siswa tiap kategori kemampuan berpikir kreatif matematis Siklus I dan siklus II

\begin{tabular}{cccc}
\hline Ketentuan & Kategori & Jumlah Siswa Siklus I & Jumlah Siswa Siklus II \\
\hline $90 \leq \mathrm{x} \leq 100$ & Sangat Baik & 0 & 4 \\
$80 \leq \mathrm{x} \leq 90$ & Baik & 4 & 10 \\
$70 \leq \mathrm{x} \leq 80$ & Cukup & 7 & 6 \\
$60 \leq \mathrm{x} \leq 70$ & kurang & 12 & 3 \\
$\mathrm{x} \leq 60$ & Sangat Kurang & 1 & 1 \\
& $\sum$ & $\mathbf{2 4}$ & $\mathbf{2 4}$ \\
\hline
\end{tabular}

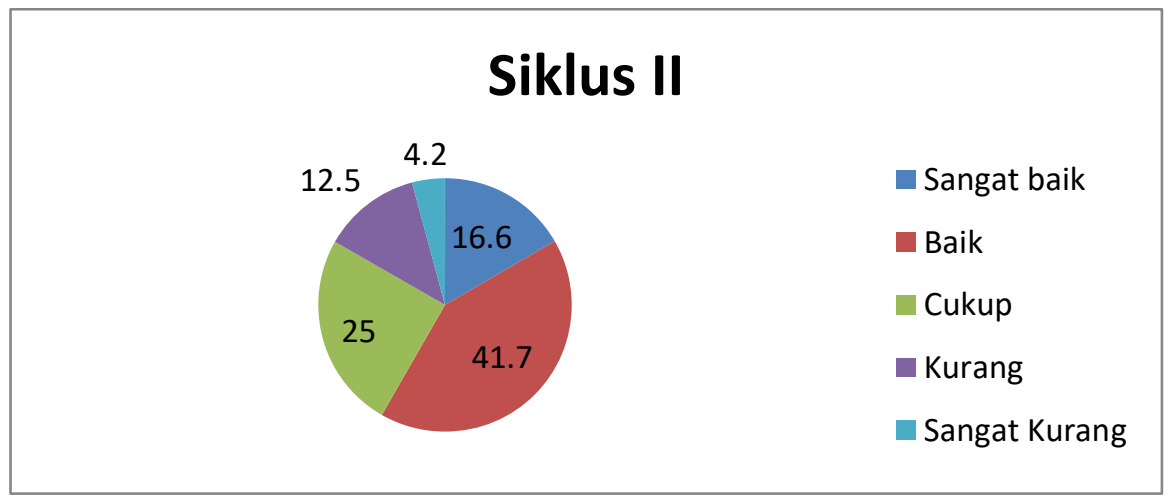

Gambar 3. Kemampuan Siswa Siklus II

Berdasarkan tabel 2 dan gambar 2, rata-rata nilai yang diperoleh siswa adalah sebesar 82,2 nilai maksimal yang diperoleh siswa adalah 96 dan nilai minimal yang diperoleh adalah 55. Sedangkan terjadi penurunan jumlah siswa sebanyak 9 orang siswa yaitu sebesar $37,5 \%$ siswa yang memiliki kemampuan berpikir kreatif matematis dengan kategori 'Kurang'.

II yaitu:

Hasil presentase dari siklus I ke siklus

a. Terdapat kenaikan Sebesar 16,7\% atau terdapat penambahan sebanyak 4 orang anak yang memiliki kemampuan berpikir kreatif matematis dengan kategori 'Sangat Baik’ dari sebelumnya pada siklus I.

b. Terdapat kenaikan Sebesar 25\% atau terdapat penambahan 6 orang anak yang memiliki kemampuan berpikir kreatif matimatis dengan kategori 'Baik'. c. Berkurang satu orang anak atau terdapat penurunan sebesar $4,2 \%$ anak yang memiliki kemampuan berpikir kreatif matematis dengan kategori 'Cukup'.

d. Berkurang sebanyak 9 orang anak atau terdapat penurunan sebesar 37,5\% anak yang memiliki kemampuan berpikir kreatif matimatis dengan kategori 'Kurang'.

e. Tidak ada kenaikan atau penurunan jumlah anak yang memiliki kemampuan berpikir kreatif matematis.

Data yang didapatkan berdasarkan jawaban siswa yang telah dianalisis sesuai dengan rubrik jawaban dan pedoman penskoran yang mencakup aspek fluency, flexibility, originality dan elaboration. Hasil perhitungan ketercapaian berpikir kreatif matematis tercantum dalam tabel 3. 
Tabel 3. Ketercapaian Aspek Berpikir Kreatif

\begin{tabular}{ccccc}
\hline $\begin{array}{c}\text { Aspek-aspek kemempuan } \\
\text { berpikir kreatif }\end{array}$ & $\begin{array}{c}\text { Rata-rata } \\
\text { siklus I }\end{array}$ & Kategori & $\begin{array}{c}\text { Rata-rata } \\
\text { Siklus II }\end{array}$ & Kategori \\
\hline Kelancaran (Fluency) & 71,2 & Cukup & 82,3 & Baik \\
Keluwesan (Flexibility) & 76,8 & Cukup & 83,2 & Baik \\
Keaslian (Originality) & 75,3 & Cukup & 81,2 & Baik \\
Memerinci (Elaboration) & 62,1 & Kurang & 71,5 & Cukup \\
\hline
\end{tabular}

Berdasarkan tabel pencapaian aspek berpikir kreatif, pada aspek Kelancaran (Fluency) rata-rata yang diperoleh pada siklus I sebesar 71,2 dengan kategori Cukup meningkat menjadi sebesar 82,3 dengan kategori Baik. Kelancaran dalam keterampilan berpikir yang dimaksudkan adalah siswa dapat menghasilkan banyak gagasan atau jawaban yang relevan disertai dengan arus pemikiran yang lancar (Munandar, 2009). Soal pada indikator ini mengidentifikasi kelancaran yang diwujudkan dengan menyelesaikan permasalahan yang berkaitan dengan KPK dan FPB.

Aspek Keluwesan (Flexibility) yang diperoleh dari hasil tes mengalami peningkatan. Pada Siklus I sebesar 76,8 dengan kategori Cukup meningkat menjadi sebesar 83,2 dengan kategori Baik. Keluwesan (Flexibility) diartikan sebagai mampu menghasilkan gagasan, jawaban, atau pertanyaan yang bervariasi. Soal pada indikator ini mengidentifikasi cara siswa dalam memecahkan atau menyelesaikan soal,

Aspek Keaslian (Originality) yang diperoleh dari hasil tes mengalami peningkatan angka dari rata-rata sebesar 75,3 dengan kategori Cukup menjadi sebesar 81,2 dengan kategori Baik. Keaslian (Originality) diartikan mampu memberikan gagasan yang baru dalam menyelesaikan masalah atau memberikan jawaban yang lain dari yang sudah biasa dalam menjawab suatu pertanyaan/soal (Haerudin, 2011). Soal pada indikator ini mengidentifikasi siswa dalam membuat ungkapan/pertanyaan baru yang unik atau cara lain (berbeda) dalam menyelesaikan soal/masalah.
Memerinci (Elaboration) diartikan mampu memperkaya dan mengembangkan suatu gagasan atau produk (Haerudin, 2011:289-290) soal pada indikator ini mengidentifikasi siswa dalam memerinci cara penyelesaian dari soal atau permasalahan yang diberikan. Aspek Memerinci (Elaboration) yang diperoleh dari hasil tes mengalami peningkatan dari rata-rata sebesar 62,1 dengan kategori kurang menjadi rata-rata sebesar 71,5 dengan kategori Cukup.

\section{SIMPULAN}

Berdasarkan hasil penelitian yang telah dilaksanakan di kelas IV SDN 101/X Lambur I dan data-data yang diperoleh peneliti menarik kesimpulan pembelajaran kooperatif tipe Open-Ended dapat meningkatkan keterampilan berpikir kreatif matematis siswa. Keterampilan berpikir kreatif matematis siswa setelah penerapan model pembelajaran Kooperatif Open-Ended dari siklus I ke siklus II meningkat yaitu Terdapat kenaikan Sebesar $16,7 \%$ atau terdapat penambahan sebanyak 4 orang anak yang memiliki kemampuan berpikir kreatif matematis dengan kategori 'Sangat Baik' dari sebelumnya. Selain itu Terdapat kenaikan Sebesar 25\% atau terdapat penambahan 6 orang anak yang memiliki kemampuan berpikir kreatif matimatis dengan kategori 'Baik'.

\section{DAFTAR PUSTAKA}

Depdiknas. (2003). Undang-undang RI No. 20 Tahun 2003. Tentang Pendidikan Nasional.

Haerudin. (2011). Penerapan Metode SAVI dengan Pendekatan Induktif dan Peningkatan Berpikir Kreatif 
Matematis. Prosiding Seminar Nasional Pendidikan Matematika STIKIP Siliwangi Bandung. Volume 1 tahun 2011:287-291).

Isjoni. (2013). Cooperatif Learning: Mengembangkan Kemampuan Belajar Kelompok. Bandung: Alfabeta).

Kurnia Eka Lestari \& Mokhammad Ridwan Yudhanegara. (2017). Penellitian Pendidikan Matematika. Bandung:PT.Refika Aditama.

Munandar., Utami. (2009). Pengembangan Kreatifitas Anak Berbakat. Jakarta: Rineka Cipta.

Rafianti, Yani dan Novaliyosi. (2018). Profit Kemampuan Literasi Kuantitatif Calon Guru Matematika. JPPM, 11 (1):63-74. 